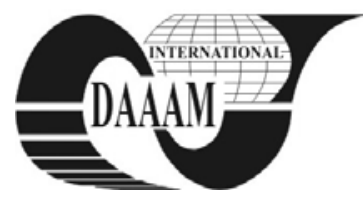

\title{
ANALYSIS OF THE MAIN FACTORS OF OPTIMISATION OF LONG TERM FINANCING STRUCTURE OF ROMANIAN ENTERPRISES
}

\author{
VINTILA, G[eorgeta]; ARMEANU, D[aniel] \& NEDELESCU, M[ihai]
}

\begin{abstract}
The financial structure of the enterprise represents a subject of permanent interest in specialized literature. Adopting a certain financial structure represents an important aspect of the financial policy of the enterprise. The decision regarding the financial structure of the enterprise depends on its economic growth objectives, the level of the expected return and the assumed risks, as well as on the shareholders, investors and financial institutions. When talking of enterprises, capitals are fewer and fewer, more and more expensive, and, in a context of strong competence, the expected profit is obtained with more difficulty, taking greater risks which are hard to anticipate and diminish.
\end{abstract}

Key words: capital structure, cost of the capital, financial leverage, multiple regression

\section{INTRODUCTION}

In the current period of deep financial disturbances at both macro and micro-economic levels, capital owners select investment with much more attention, by comparing the dividend rate, offered by the enterprise, and the interest rate of the banck or the profit rate obtained from other investments. Under these circumstances, it is certain that the situation and the image of the enterprise depend on the profit rate which, if looked at in terms of the use of profit as development source and as a method to gain capitals, ultimately determines the place of the enterprise on the market (Vintila, 2008).

If an enterprise wants to ensure an economic and financial balance and the expected profit, it has to ensure itself an optimal structure of capital, which is nevertheless easy to prescibe but hard to achieve. The capital structure of an enterprise, or the so-called mixed capital between ownership equity and debts, represents one of the most debated subjects in theoretical and applied finance. Thus, beginning with Miller \& Modigliani's classical theory (1958) and continuing with the modern theories, there has been a permanent preoccupation of surprising, analysing and interpreting of the factors that influence the financial decision of the enterprise both in a national and international context.

In the case of Romania - maybe more than in the case of other countries - the optimisation of the capitals structure is more difficult and sprinkled with problems that are more difficult to solve. The need of capital the Romanian enterprises are confrunted with greatly depends on the way these handle the informational elements regarding the capitals, their formation sources, their cost, the capital allocation and use, the obtainable capitals, the projects profitability, the profitable valorification of the existant own capitals, etc. Moreover, considering the particular problems Romania is dealing with, and as long as we are aware of the mentioned risks, approaching the issue of optimisation the long-term financing structure of the enterprise is an absolute and doubtless necessity.

The research is applied on a sample of 60 enterprises listed at Bucharest Stock Exchange (BVB) having the aim to analys the main factors of influence of financing structure of romanian enterprises. The reason the chosen companies were from those listed at BVB is that a company is admited at BVB on certain performance criteria and the lisitng represents an award for the efficient acitvity of the company.

\section{ANALYSIS MODEL OF INFLUENCIAL FACTORS ON THE FINANCIAL STRUCTURE OF ENTERPRISES}

With regard to the structure of the capitals of the Romanian enterprises there have been a multitud eof empirical studies based on Miller \& Modigliani's classical model as well as on odern theories about capitals structure. Therefore, the researchers' interest consisted in testing the hypotheses that are the fundamentals of the trade off and pecking order theories. Their aim was to idnetify the theory whcih best expleins the financial behaviour of Romanian enterprises. Empirical studies realised by Romanian specialists like (Dragotă, 2005; Ivănescu, 2006; Darie, 2008) with regard to the finacing structure of local companies follow the international tendency. Thus, according to studies by (Booth et al., 2001), Romanian enterprises follow the trend of developing countries.

Determining an optimal financing structure is one of the managers' main objectives and at the same time problem which is difficult to be solved at a practical level. By means of econometric instruments, this study tried to analyse the impact of some factors, considered to be determining for the financial structure, on the average weighted cost of the enterprise capital (CMP) and on the finacial leverage (LEV) and also to identify that theoretical model based on classical and modern theories. Considering the above, the empirical analysis of the financial data was made by two multiple regression models:

- The first model analyses the influence of six factors (financial leverage LEV, weight of fixed assets in the total assets PAI, rate of financial autonomy RAF, debts rate RDAT, economic rentability ROA and financial rentability ROE) on CMP;

- The second model analyses the influence of five factors (weight of fixed assets in the total assets PAI, rate of financial autonomy RAF, economic rentability ROA and financial rentability ROE as well as interest rate RDOB) on LEV.

2.1 Econometric analysis of the main factors of the average weighted cost of the capital of the enterprise (CMP)

Following the statistical tests of corelation, the result was that only three of the six independent variables are significant from a statistic point of view. Thus, the tested regression model will have the following form:

$$
C M P_{i t}=\alpha_{0}+\alpha_{1} L E V+\alpha_{2} P A I+\alpha_{3} R O E
$$

The results obtained with the help of the regression model reflect the fact that the independent variables taken into consideration explain in a great measure the evolution of the analyzed dependent variable (Tab 1). 


\begin{tabular}{|l|l|}
\hline LEV & $\begin{array}{l}\text { The leverage rate registered in the Romanian level, } \\
\text { according to the regression model, presents a } \\
\text { positive corelation reported to the average weighted } \\
\text { cost of the capital. This suggests that indebted } \\
\text { enterprises have a bigger average weighted cost } \\
\text { than those less indebted. }\end{array}$ \\
\hline PAI & $\begin{array}{l}\text { According to the regression model, PAI presents a } \\
\text { negative correlationin report to the CMP dependent } \\
\text { variable. This highlights the fact that locat } \\
\text { enterprises listed at BVB choose financing from } \\
\text { own sources or leveling up the indebtness degree } \\
\text { when deciding to grow the assets. }\end{array}$ \\
\hline ROE & $\begin{array}{l}\text { According to out of the regression model, ROE } \\
\text { present a positive correlation in report to the } \\
\text { dependent variable CMP. ROE is a synthetical } \\
\text { indicator which expresses the capacity of the } \\
\text { enterprise to issue profit through own capitals } \\
\text { engaged in its activity abd the shareholders' } \\
\text { remuneration degree. }\end{array}$ \\
\hline
\end{tabular}

Tab. 1. Analysis of the influential factors of the capital structure of the enterprise according to the regression model (CMP)

\subsection{Econometric analysis of the main factors of the financial leverage (LEV)}

Following the statistical tests of corelation, the result was that only three of the six independent variables are significant from a statistic point of view. Thus, the tested regression model will have the following form:

$$
L E V_{i t}=\alpha_{0}+\alpha_{1} P A I+\alpha_{2} R O E
$$

Following the estimations of the parameters of the regression model, the result was the following output (Tab 2):

\begin{tabular}{|l|l|}
\hline PAI & $\begin{array}{l}\text { According to the regression model elaborated for } \\
\text { local comapnies, the PAI presents a negative } \\
\text { corrrelationin report to the LEV dependent } \\
\text { variable. This highlights the fact that locat } \\
\text { enterprises listed at BVB choose financing from } \\
\text { own sources or leveling up the indebtness degree } \\
\text { when deciding to grow the assets. }\end{array}$ \\
\hline ROE & $\begin{array}{l}\text { According to out of the regression model, ROE } \\
\text { present a positive correlation in report to the } \\
\text { dependent variable LEV. ROE is an which } \\
\text { expresses the capacity of the enterprise to issue } \\
\text { profit through own capitals engaged in its activitz } \\
\text { abd the shareholders' remuneration degree. }\end{array}$ \\
\hline
\end{tabular}

Tab. 2. Analysis of the influential factors of the capital structure of the enterprise according to the regression model (LEV)

From the evolution of the influential factors followed during the 5 years of analysis we can observe that not all the independent variables of the two models are significant from a statistic point of view (Armeanu \& Lache, 2008). We tried to identify the determining factors of the average weighted cost of that capital, and of the financial leverage with the help of the method of analysis of main components. After assessing the data with the help of the Statistica 10 program, the following output resulted:

1. Of the six independent variables of the first regression model (CMP) only the financial leverage (LEV), weight of fixed assets in the total assets (PAI) and the financial rentability rate (ROE) are determining factors that influence significantly the average weighted cost of the capital of the enterprise: about $47 \%$ of the CMP variation is explained by LEV and ROE and about $33 \%$ of the CMP variation is explained by PAI. In othrer words, an optimal financing structure could be determined by the control of the financial leverage of the enterprise ( $L E V)$, of the weight of fixed assets (PAI) and of the financial rentability (ROE).
2. Of the five independent variables of the second regression model (LEV) only the weight of fixed assets in the total assets (PAI) and the financial rentability (ROE) are determining factors as regard to the evolution of the financial leverage (about $62 \%$ of the LEV variation being explained by the weight of fixed assets in the total assets of the enterprise and the financial rentability). In othrer words, an optimal financing structure could be determined by the control of the weight of fixed assets (PAI) and of the financial rentability (ROE).

\section{CONCLUSION}

The analysis of the capital structure of the enterprises listed at BVB betwenn underlines that the main financing source is represented by ownership equity having an approximatively $58 \%$ weight, the rest of the capitals coming from external sources, especially from stock emission and long-term and short-term bank loans. This analyse highlights the fact that Romanian enterprises try to cover the financing necessary especially by means of own sources and only when these reached the limit do manager try to look for external sources: bank credits, leasing, stock emission firstly and bonds emission secondly. Also, as far as the structure of the debts listed at BVB in 2006-2010 it is obvious that the management of these enterprises prefer debts with due date shorter than one year to debts with due date longer than one year. This tendency of managers engaging debts on rather short terms can be expleined by the restrictive conditions imposed by Romanian financial institutions when approving long-term loans. Guided by what has been presented above, we could conclude that the financing structure generally used by Romanian enterprises is in accordance with e the principles of the pecking order theory. That means that the company will try to cover the financing necessary from own sources firstly and only after having reached its limit does is try to call for external financing. We could also observe that external financing generally comes from credits, and, as far as time as a factor is concerned, managers of the local companies prefer endebting on short periods of time to indebting on long periods of time. This preferance for shortterm loans can be explained through the restrictions imposed by the financial instituitions when giving long-term loans.

\section{ACKNOWLEDGEMENTS}

This article is a result of the Exploratory Research Project PN-II-ID-PCE-2008-2, no. 1764, CNCSIS, financed from the state budget through the Executor Unit for Superior Education and Scientific Research Activity Financing UEFISCSU.

\section{REFERENCES}

Armeanu, D. \& Lache, L. (2008) Application of the Model of Principal Components Analysis on Romanian Insurance Market, Theoretical and Applied Economics, AGER, vol. 6., ISSN 1841-8678

Booth, T., Aivazian, V., Demirguc-Kunt, A., Maksimovic, V. (2001) Capital structures in developing countries, Journal of economics, no.LVI, pag.87-130

Darie, A. (2008) Analiza financiara in mecanismul de formare a surselor de finantare a intreprinderii, Publisher ASE, Bucharest

Dragota, M. (2005) Analiza factorilor determinanti ai politicii de finantare a societatilor comerciale listate pe piata de capital, Publisher ASE, Bucharest

Ivanescu, D.N. (2006) Analiza factorilor determinanti ai structurii de financiare a intreprinderii, Publisher ASE, Bucharest

Vintila, G. (2008) Gestiunea financiara a intreprinderii, Publisher EDP, ISBN 973-30-2358-2, Bucharest 